\title{
宇根豊の減農薬稲作から農本主義への思想展開
}

\author{
大石 和男 1$) *$
}

\section{Une's Idealistic Path from a Reducing Chemical Method to Agrarianism}

\author{
Kazuo Oishi ${ }^{1) *}$
}

\begin{abstract}
Agrarian thoughts are a type of social thought, but their characteristics are not sufficiently clear. One reason is that some thoughts that share the same keywords are given different names. This might show that the originalities of these thoughts are not based on their ideal novelty but on how to combine contemporary issues with agrarian affairs. To consider this point, this paper focuses on two concepts based on less (no) chemical methods: Y. Une's method for reducing chemicals; and general organic agriculture. These ideas have been developed with a similar viewpoint with regard to social change, but they were not integrated. Therefore, they should not be understood as having a linear relationship simply because
\end{abstract}

both involve reducing the volume of chemicals. A hypothesis in this paper is that they have different images of social change as goals. To compare them, a tetrahedron model was adopted that has four vertices, each assigned to one element. The four vertices represent human, technology, social system, and nature. Une is a thinker who produced a method of growing rice while reducing pesticides and has developed this process as a social thought. Finally, he reached the ideas of agrarianism, integrating over 40 years of considerations. His goal was to establish a new agrarian norm against modernity. This distinguishes Une's thoughts from general organic agriculture, which prioritizes social extensions.

\section{キーワード：宇根豊, 農本主義, 減農薬, 思想, 有機農業}

\section{1. はじめに}

\section{（1）農的思想の研究が抱える弱点}

農的思想を考えるに際して，倫理をめぐる近年の 顕著な動向（たとえば SDGs の推進）は気になる存 在である. その理由は, 倫理の掲げる目的（ここで は「善」の探求と簡潔に設定して报く）が, 社会変 革を目指す農的思想としばしば重なり合ってきたに も関わらず，両者の違いについてこれまであまり意 識されてこなかったからである. 異同に関する考察 が手薄となっている理由は, 少なくとも思想研究の 側において 2 点考えられる.

まず 1 点目は，それぞれの形態の違いに起因する. 一般的にみて農的思想では, 変革方向を抽象的に示 した理念に加えて，その具体的かつ社会的な投影像 である実践についても強く意識を向けることが多い. つまり農的思想の特徵は, 理念と実践が不可分の関
係を形成している点にあり（たとえば「自給」の思 想), 思想を考察する際には, これらの結合様式を通 じて理念が具体化されていく道筋についても注意を 払ら必要がある。それに対して倫理ではもっぱら善 悪の基準に関する形而上の思考を得意としているた め, 双方を素朴に対照させることの困難性を指摘す ることができる.

2 点目は研究者の姿勢に関する点である。農的思 想の場合，研究者が思想や社会運動の賛同者となっ てその流れに棹差す立場をとることも少なくない. つまり思想の発展と普及に多少なりともコミットし ようとする研究が，一定の地歩を築いているのであ る.このことは思想そのものから距離を置く研究が 少ないことを意味して抢り，思想の比較分析に向け た方法論が未熟である一因となっている.

そこで本論文では農的思想の相対的評価法の欠如 という問題を念頭に掞いたらえで，「減農薬稲作」で

1) 京都大学大学院農学研究科; Graduate School of Agriculture, Kyoto University

*E-mail: oishi.kazuo.5s@kyoto-u.jp

(ㄷ地域農林経済学会 
著名な福岡の宇根豊の思想に目を向ける。そしてこ の思想を起点としながら他の思想との異同を浮かび 上がらせることのできる視角を提起し，その有効性 を確認するとともに，類似思想との比較によって見 えてくる思想間の差異の意味について解明を試みる. な特本稿では農的思想を, その特質に基づいて, 理 念と実践の二面性をもつものとして扱っていく.

\section{(2) 研究の課題}

宇根豊を取り上げる理由は 2 点ある. 第 1 の理由 は, 農法変革を起点にして開始された彼の思想が, 有機農業等の相対的位置を考无るための好素材と なっている点である，高度経済成長期以降（以下， 現代と表記）これらの農法は, 社会変革思想として の性格を帯びながら，慣行の農業・食料に対するオ ルタナティブな存在を目指すことで社会的支持を伸 ばしてきた。本稿が農法と農的思想を同一視して扱 らのもそのためであり, とりわけ 1970 年代以降の 農的思想は, 有機農業等から直接・間接的に影響を 受けたものが大半であるといっても過言ではない.

とはいえ同じく 70 年代に登場した宇根思想は, 農 薬に否定的な態度をとりながらも, 他方で有機農業 とは敢えて一線を画す立場をとってきた．このこと は, 減農薬思想が約 40 年にわたって深められてきた ことを踏まえるならば，いささか奇妙なことにも思 える. 農薬の削減を突き進めていった終着点が無農 薬であることは，ある意味自明だからである。

後述するように宇根は日本有機農業学会に深くコ ミットし, 改善策について積極的に意見を寄せなが らも，〈良き隣人〉としての立場を崩そらとはしな かった。 それゆえに, 宇根は減農薬農法と有機農業 の間に思想面で大きな違いを見出していると予想せ ざるを得ない，その理由を探ることが本稿の 1 点目 の課題となる.

第 2 の理由は農的思想全般に見られる特徵, 寸な わち異なる名称を掲げた種々の思想間で, しばしば 鍵概念の共有現象がみられることと関係する ${ }^{1} . こ$ の現象は宇根についても当てはまり, 技術的観点か ら出発した彼の減農薬思想が, 次第に「自給」や「農 本主義」といった諸概念を取り込んでいく様を確認 することができる。では概念の共有現象はいったい 何を意味しているのであろらか，結論を先に述べる ならば，これは宇根が農本主義に辿り着いたことと
深く関係している，そこで 2 点目の課題として，宇 根が「農本主義」に込めた意味内容について明らか にすることで, 農的思想に打㥩各種の鍵概念と「農 本主義」との関係について考察する.

\section{2. 先行研究}

宇根思想の比較対象として有機農業系の農法を持 ち出すことの利点は, 農的ジャンルへの関心が決し て高いとは言えない思想研究の全体動向の中で, 例 外的に多くの研究蓄積を見いだせることによる。そ こで次に, 有機農業の直面する課題を先行研究から 探りつつ，分析のための視角を考光てみたい.

昨今の日本の有機農業運動が抱える伸び悩みの理 由について，1つの示唆を与えているのは原山浩介 である. 原山は有機農業の法制化（1999 年の改正 JAS 法等）が進む状沉を踏ま兄, 技術と制度ばかり に議論が進む一方で,「社会の問題としては展開され なくなってしまっている」点を指摘する，そして「産 業社会批判や文明批判」といった発想と強く結びっ いた「周縁性」が失われ，「問題の立て方」に「硬直 性」が生じてしまっていると述べる（原山，2008： p. 170). 本稿ではこの見解を踏襲しつつ，別方面に おいても「硬直性」が生じている可能性を指摘して おきたい。

そこで取り上げたいのが, 草創期の有機農業に着 目しつつ, 長年にわたって学術面から運動の発展に 貢献してきた桝潟俊子の「〈持続可能な本来農法〉」 といら文言である（桝潟，2017）。この内容は，有 機農業の理念を純粋に表現したものとしては十分に 妥当性を有している反面，社会運動に打沙理念を 相対的に捉える研究がいくつも登場している中で, 「本来」の内容を静的に捉えることが果たして適切な のかといら若干の疑問が勈かないでもない.

かつて谷口吉光は, 提携運動の内部に存在する対 立や葛藤の原因を探ることで,「提携運動が絶えず変 質し，完結などしない運動」となっていることを見 いだし，「目標達成を志向する運動ではない」と結論 づけている(谷口, 1989 : p. 92)。ささらに大石和男 は思想が運動や実践へと転化される際に発生する理 念と実践の差異に着目し，そこに動的から有意味な 関係の存在することを述べる（大石，2017）。すな わち思想の理念が具体的な実践形態へと翻訳されて 
いく過程に沶いては, 内容の吟味や再解釈が避け光 ず，それが参加者に理念の意味を問い続けさせ，実 践を産出させ続けることに繋がるとする研究である. つまり両者とも, 高尚な理念分析に留まるのではな

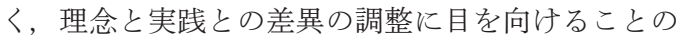
重要性を主張するのである.

もら 1 点論じて打きたいのは, 複数の農法間に打 ける発展段階論的な理解についてである。たと竞に゙ 投入資材の量といった観点から, 減農薬農法を有機 農業よりも劣る農法として位置付ける理解は段階論 的理解の代表例である（たとえば桝潟，2017: p. 16).

その一方で歷史的にみるならば, 藤井平司は 1970 年代に有機農業の主張する有機物施用を批判して無 投入の天然農法を唱えて扣り（藤井，1983: p. 15）, この観点にしたがえば昨今の有機農業は天然（また は自然）農法化してきていると言えなくもない。だ が，有機農業は自然農法等に向からための過渡的な 農法だとする見解を耳にすることはあまりない2. 自然農法を有機農業の範疇に含めながら，他方で有 機農業は低投入に向かっていると述べる中島紀一に もこのことは当てはまる（中島, $2013:$ p. 13).

したがって有機農業論には，単線的な把握法に基 づく農法の優劣問題だけに帰着させることのできな い別種の価値基準が暗黙理に設定されていると考光 るしかなく，このような実態を十分にすくい取れて いない分析視角もまた硬直性を抱光込んでいるょう に思われる。

実はこの問題を乗り越える視点をもった研究も少 しずつ生まれている。谷川彩月は「慣行農家による 減農薬栽培の導入プロセス」に目をむけ, 「多様な価 值の『ズレ』を積極的に評価し，それを内包させて いくよらな環境保全のあり方」を考光る必要性を指 摘している (谷川, $2017:$ p. 116). ここには単一の 思想理念に収斂しょうとしない実践者たちの価値観 に目を向け，十把一絡げに理念への同化を迫るので はなく，多様性をもった意識や実践の中から積極的 意義を汲み取っていこうとする視点が見られるので ある.これは, 理念の絶対視とは異なる経路から思 想や運動の姿を捉えていこうとする点で, 本稿の視 角と重なっている.

\section{3. 分析視角}

\section{（1）理念を巡る思惑の違い}

日本の有機農業は，いくつかの先駆的な事例 ${ }^{3} の$ あとをらけつつ, 1971 年の（日本）有機農業研究会 の誕生をもって本格化していった，結成趣意書に挙 げられた大きな論点は，1．農業者の農薬中毒， 2 . 消費者の食の安全 (「食品公害」)，3．生態系の破壊， 4. 環境污染, 5. 農地の地力減退であり, これらへ の対応として構想されたのが有機農業であった（有 機農業研究会, 1972)。そして 80 年代に入ると, 生 産者和よび消費者を一体化した提携運動の取り組み によって運動の普及に弾みがつくようになり，2000 年代以降は有機 JAS 法や有機農業推進法を押し進め ることで，法律や認証基準による制度化の道を迻っ ていった.

ただし当初に意識されていた問題群のらち，農業 者の健康問題（農薬被害）や生態系への配慮につい ては，省農薬運動（石田，2018：pp. 107-142）や兵 庫県豊岡市でのコウノトリプロジェクト（中村, 2009）といった別種の活動が次第に存在感を増すよ らになる。ここで有機農業研究会の結成に多少関与 した自然農法提唱者の福岡正信に触孔てみよう。

この会 (=有機農業研究会一引用者) の名前を, 有機農法にするかどらかといらときに，相談を受 けて，私は...「自然農法」ではだめなのか，と言っ たら，これはやっぱり宗教くさいから ...有機農法 といら言葉を使った。....しかし私はそのとき...危 惧はもったんです。...有機農法は...西洋哲学の考 光に出発し，科学農法の一部にすぎないのではな いか, と. ...最終の目標っていらものは...人間完 成のための農法になってなきやいけないんだ（福 岡, 1975 : pp. 164-166, 傍点扣よび改行省略, ... は引用者による中略，以下同様）。

一樂照雄らが展開した有機農業と福岡正信の主唱 した自然農法とは，それなりに近い関係にあったも のの，結局の所，両者は統合されることなく別々の 道を歩んでいく，その理由は，根幹をなす理念の位 置づけに大きな違いがあったからに他ならない，し たがって思想間の差異を検証するにあたっては，単 


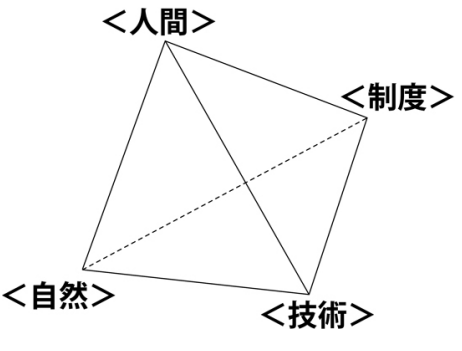

図1. 四面体型の分析モデル

に技術的距離だけにとどまらず，農法に込められた 理念の方向性にも目を向ける必要があるといえる.

\section{（2）農法比較に向けた分析視角}

そこで本稿では比較対象として有機農業を念頭に おきながら，思想相互の比較を可能とする枠組みを 設ける。ただしそれぞれが揭げる主張は多岐に渡る ため，網羅的な内容の比較は困難である，そこで思 想間の違いを浮き立たせるために，四面体型の独自 の分析モデル4を図 1 に提示してみたい.

このモデルの特徴は，4つの要素を各頂点に配置 し，思想に登場する概念や実践を， 2 要素の結合体 である 6 つの辺〉に位置づけて理解しょらとする 点である，その上で，思想ごとの指向性の違いにつ いては，最も強調されている〈面〉の違いとして捉 えていくこととする. つまり分析モデル上の〈辺〉 $\rightarrow\langle$ 面〉の順に要素間の関係を眺めていくことで, それぞれの思想の性格を模式的に理解し, 思想間の 相違点の把握へと慗げていきたいのである.

な扮分析の出発点となる 4 つ要素については, 事例の特性を踏ま元，それぞれ〈人間〉〈自然〉〈技 術〉〈制度〉を割り当てることとする.

\section{4. 宇根豊について}

\section{(1) 経歴}

宇根の経歴を表 1 に示しておく. 彼は長崎県島原 地方の農家に生まれ，少年期より実家の生業である 養鶏に親しみを感じつつ, 他方で農業の近代化に伴っ て規模拡大に突き進むこととなった経営スタイルに 嫌悪感も抱いてきた.

大学 (農学部) 卒業後に福岡県で農業改良普及員 の職を得た彼が転機を迎えたのは，ある農業者から 発せられた「農薬を使わせ過ぎる」の一言である.
表 1. 宇根豊の経歴

\begin{tabular}{|c|c|}
\hline 年 & 事項 \\
\hline 1950 & 長崎県島原市の養鷄農家に生まれる. \\
\hline 1973 & $\begin{array}{l}\text { 九州大学農学部卒業後, 福岡県筑紫農業改良普及所 } \\
\text { に勤務. }\end{array}$ \\
\hline 1977 & 桐谷圭司『害虫とたたから』に出合ら。 \\
\hline 1978 & 八尋幸隆 (農家) と減農薬稲作の実験を開始. \\
\hline 1979 & $\begin{array}{l}\text { 筑紫野減農薬稲作研究会発足 (参加者 } 15 \text { 名). } \\
\text { 虫見板の誕生. }\end{array}$ \\
\hline & 山下惣一らと第 1 回九州百姓出会いの会を開催. \\
\hline 1982 & $\begin{array}{l}\text { 除草剂 CNP（商品名 } \mathrm{MO} \text { ）事件, 農水省より圧力を } \\
\text { 受ける. }\end{array}$ \\
\hline 1984 & 『減農薬稲作のすすめ』を自費出版. \\
\hline 1985 & $\begin{array}{l}\text { 西日本でウンカ大発生による減収, 減農薬田の被害 } \\
\text { は軽微. }\end{array}$ \\
\hline 1989 & $\begin{array}{l}\text { 糸島郡二丈町（現糸島市）にて新規就農（勤務も継 } \\
\text { 続). }\end{array}$ \\
\hline & $\begin{array}{l}\text { 『田の虫図鑑』を出版し「ただの虫」という視点を } \\
\text { 提唱. }\end{array}$ \\
\hline 1994 & 糸島環境稲作研究会を結成. \\
\hline 1999 & 大学院に社会人入学. \\
\hline 2000 & 福岡県庁を退職. \\
\hline & 「NPO 法人 農と自然の研究所」を設立. \\
\hline 2001 & 田んぼの生き物調査を開始. \\
\hline 2003 & $\begin{array}{l}\text { 亀井善之農水大臣に「日本版デ・カップリング」を } \\
\text { 提言. }\end{array}$ \\
\hline 2010 & $\lceil\mathrm{NPO}$ 法人 農と自然の研究所」を解散. \\
\hline
\end{tabular}

資料：佐藤弘（2008）をもとに筆者作成.

この批判は従来型の普及指導への見直しを宇根に迫 ることとなり，彼は農業者と共に研究を開始し(1978 年), 翌年には減農薬稲作の象徵たる「虫見板」も誕 生した。

この農法が脚光を浴びるよらになったのは 1985 年である。一般的な普及指導に従って農薬を使用し ていた水田がウンカの大発生によって軒並久甚大な 被害を受ける中，世間の予想に反して減農薬稲作田 では軽微な被害に留まったのである。この出来事は 減農薬の効果をまざまざと見せつけ，人々の評価を 一躍高めることとなった。

その後もこの農法の技術確立と普及に情熱を燃や した宇根は，2000 年に県庁を早期退職し，NPOを 
設立して減農薬運動に身を捧げることを決意する. そして多くの仲間と共に田んぼの生き物調査を実施 し，5,470 種からなる「田んぼの生きもの全種リス 卜」を完成させ，著述作業にも精力的に取り組んで いく. 2010 年には公約通り NPO を解散するものの, その後も個人としての活動は継続している.

\section{（2）分析資料}

宇根には 2018 年までに少なくとも 450 点以上の 論考が確認でき, その大半は雑誌への寄稿である. 著書も主要なもので約 30 点を数える. これらの中か ら連載記事や著名雑誌への寄稿を中心に, 重要度の 高い著作約 400 点を分析対象とした。

\section{5. 「減農薬稲作」の思想と実践}

本節では論考内容打よび経歴の変化をもとに 4 期 からなる時期区分を設定し，各時期における思想の 流れを整理する。まずはこれまでの論考について， 鍵概念の登場頻度を時期ごとに整理したものを表 2 に揭げておく。

\section{（1）第 1 期：減農薬稲作確立期（1977～92）}

虫見板を用いた害虫観察と農薬施用量の自主決定 を組み合わせることで減農薬稲作を確立し，それを 福岡県下に普及せしめた点で, 宇根を特色づける重 要な活動成果の生み出された時期である。技術的な 取り組みが中心であり, 著作数は少ないものの,「農 薬をふると，かえって虫が増える」（宇根，1984） といらリサージェンス現象の確認は, 彼が自然界に 深く目を向けるきっかけとなった.
もらひとつの重要な点は，農業者にとって技術と は何かを問う姿勢がすでに見られることである，減 農薬を標榜する直前に書かれた『『手入れ』としての 技術を問ら」（宇根，1977）では，技術の導入によっ て農業者の「手入れ」の気持ちが崩壊することへの 危惧と，技術に対する農業者の主体性回復の必要性 が述べられて抢り，宇根の「百姓」論の原点となっ ている.ここで彼が発起人となった「九州百姓出会 いの会」の呼び掛け文を揭げて抽こう.

出会いを百姓の手で創りだすことができないだ ろらか...私たちの全く知らない所に，会いたくな るような百姓が，もっともっといるだろらと胸を 震わせるのです．...百姓を続けることがすでに一 つの運動であら㸚ばならない時代に一人一人の想 いを聞いてみたいものです（佐藤弘，2008:p. 122 所收).

この文章に端的に示されているように，彼にとっ て「百姓」とは単なる農業従事者ではなく, 志を胸 に秘めながら能動的に農と社会の関係を作り替えて いく希有な存在であった．理念的存在としての「百 姓」に対する強い希求を，この時期から見て取るこ とができよう。

\section{（2）第 2 期：視点拡張期（1993～99）}

宇根の視点が飛躍的な拡大を見せるのは 93 年か らである，従来の論点であった減農薬稲作にまつわ る技術とその普及といった生産的観点を越えて，農

表 2. 鍵概念の時期的変遷

\begin{tabular}{|c|c|c|c|c|c|c|c|c|c|c|c|c|c|c|c|c|c|}
\hline $\begin{array}{l}\text { 時 } \\
\text { 期 } \\
\text { 年 }\end{array}$ & $\begin{array}{l}\text { 分 } \\
\text { 晳 } \\
\text { 著 } \\
\text { 数 }\end{array}$ & 百 & $\begin{array}{l}\text { 技 } \\
\text { 術 }\end{array}$ & $\begin{array}{l}\text { 虫 } \\
\text { 省 }\end{array}$ & $\begin{array}{l}\text { 環 } \\
\text { 境 }\end{array}$ & 鼻 & $\begin{array}{l}\text { デ } \\
\text { カ環 } \\
\text { ⿳境 } \\
\text { プ支 } \\
\text { リ払 } \\
\text { ンい } \\
\text { グ }\end{array}$ & $\begin{array}{l}\text { た } \\
\text { た } \\
\text { の } \\
\text { 虫 }\end{array}$ & $\begin{array}{l}\text { w } \\
き \\
\text { む } \\
\text { の }\end{array}$ & $\begin{array}{l}\text { 生 } \\
\text { 物 } \\
\text { 多 } \\
\text { 様 } \\
\text { 性 }\end{array}$ & $\begin{array}{l}\text { 多 } \\
\text { 面 } \\
\text { 的幾 } \\
\text { 能 }\end{array}$ & $\begin{array}{l}\text { ま } \\
\text { な } \\
己 \\
己\end{array}$ & $\begin{array}{l}\text { 農 } \\
\text { 本 } \\
\text { 街 } \\
\text { 義 }\end{array}$ & $\begin{array}{l}\text { 筫 } \\
\text { 給 }\end{array}$ & $\begin{array}{l}\text { 風 } \\
\text { 景 } \\
\text { 景 } \\
\text { 観 }\end{array}$ & $\begin{array}{l}\text { 有 } \\
\text { 機 } \\
\text { 農 } \\
\text { 業 }\end{array}$ & \\
\hline $\begin{array}{c}\text { 第 } 1 \text { 期 } \\
(1977-1992)\end{array}$ & (13) & $\begin{array}{c}11 \\
(84.6) \\
\end{array}$ & $\begin{array}{r}10 \\
(76.9) \\
\end{array}$ & $\begin{array}{r}8 \\
(61.5) \\
\end{array}$ & $\begin{array}{c}0 \\
(0)\end{array}$ & $\begin{array}{c}3 \\
(23.1) \\
\end{array}$ & $\begin{array}{c}0 \\
(0) \\
\end{array}$ & $\begin{array}{c}1 \\
(7.7) \\
\end{array}$ & $\begin{array}{c}0 \\
(0) \\
\end{array}$ & $\begin{array}{c}0 \\
(0) \\
\end{array}$ & $\begin{array}{c}0 \\
(0) \\
-\end{array}$ & $\begin{array}{c}0 \\
(0) \\
\end{array}$ & $\begin{array}{c}0 \\
(0) \\
-\end{array}$ & $\begin{array}{c}0 \\
(0) \\
\end{array}$ & $\begin{array}{c}0 \\
(0) \\
\end{array}$ & $\begin{array}{c}0 \\
(0) \\
\end{array}$ & \\
\hline $\begin{array}{c}\text { 第 } 2 \text { 期 } \\
(1993-1999)\end{array}$ & (15) & $\begin{array}{c}14 \\
(93.3) \\
\end{array}$ & $\begin{array}{c}14 \\
(93.3) \\
\end{array}$ & $\begin{array}{c}10 \\
(66.7) \\
\end{array}$ & $\begin{array}{c}13 \\
(86.7) \\
\end{array}$ & $\begin{array}{c}11 \\
(73.3) \\
\end{array}$ & $\begin{array}{c}8 \\
(53.3) \\
\end{array}$ & $\begin{array}{c}7 \\
(46.7) \\
\end{array}$ & $\begin{array}{c}7 \\
(46.7) \\
\end{array}$ & $\begin{array}{c}3 \\
(20.0)\end{array}$ & $\begin{array}{c}0 \\
(0) \\
\end{array}$ & $\begin{array}{c}1 \\
(6.7)\end{array}$ & $\begin{array}{c}0 \\
(0) \\
\end{array}$ & $\begin{array}{c}2 \\
(13.3)\end{array}$ & $\begin{array}{c}3 \\
(20.0)\end{array}$ & $\begin{array}{c}4 \\
\text { (26. } 7) \\
\end{array}$ & 下段：(\%) \\
\hline $\begin{array}{l}\text { 第3 期 } \\
(2000-2010)\end{array}$ & $(341)$ & $\begin{array}{l}228 \\
(66.9)\end{array}$ & $\begin{array}{c}86 \\
(25.2)\end{array}$ & $\begin{array}{c}27 \\
(7.9)\end{array}$ & $\begin{array}{c}99 \\
(29.0)\end{array}$ & $\begin{array}{l}125 \\
(36.7)\end{array}$ & $\begin{array}{c}46 \\
(13.5)\end{array}$ & $\begin{array}{c}34 \\
(10.0)\end{array}$ & $\begin{array}{l}107 \\
(31.4)\end{array}$ & $\begin{array}{c}55 \\
(16.1)\end{array}$ & $\begin{array}{c}50 \\
(14.7)\end{array}$ & $\begin{array}{c}46 \\
(13.5)\end{array}$ & $\begin{array}{l}43 \\
(12.6)\end{array}$ & $\begin{array}{l}33 \\
(9.7)\end{array}$ & $\begin{array}{l}33 \\
(9.7)\end{array}$ & $\begin{array}{l}22 \\
(6.5)\end{array}$ & $\begin{array}{c}\text { 凡例 } \\
10 \% \text { 未満 } \\
\end{array}$ \\
\hline $\begin{array}{c}\text { 第 } 4 \text { 期 } \\
(2011-2018)\end{array}$ & $(32)$ & $\begin{array}{c}31 \\
(96.9)\end{array}$ & 11 & $\begin{array}{c}4 \\
(12.5)\end{array}$ & $\begin{array}{c}7 \\
(21.9)\end{array}$ & $\begin{array}{c}15 \\
(46.9)\end{array}$ & $\begin{array}{c}9 \\
(28.1)\end{array}$ & $\begin{array}{c}9 \\
(28.1)\end{array}$ & $\begin{array}{c}18 \\
(56.3)\end{array}$ & $\begin{array}{c}8 \\
(25.0)\end{array}$ & $\begin{array}{c}4 \\
(12.5)\end{array}$ & $\begin{array}{c}17 \\
(53.1)\end{array}$ & $\begin{array}{c}15 \\
(46.9)\end{array}$ & $\begin{array}{c}5 \\
(15.6)\end{array}$ & $\begin{array}{c}6 \\
(18.8)\end{array}$ & $\begin{array}{c}9 \\
(28.1)\end{array}$ & \begin{tabular}{|l}
$10-25 \%$ 未満 \\
$25-50 \%$ 未満
\end{tabular} \\
\hline (計) & $(401)$ & $\begin{array}{c}284 \\
(70.8)\end{array}$ & $\begin{array}{c}121 \\
(30.2)\end{array}$ & $\begin{array}{c}49 \\
(12.2)\end{array}$ & $\begin{array}{c}119 \\
(29.7)\end{array}$ & $\begin{array}{c}154 \\
(38.4)\end{array}$ & $\begin{array}{c}63 \\
(15.7)\end{array}$ & $\begin{array}{c}51 \\
(12.7)\end{array}$ & $\begin{array}{c}132 \\
(32.9)\end{array}$ & $\begin{array}{c}66 \\
(16.5)\end{array}$ & $\begin{array}{c}54 \\
(13.5)\end{array}$ & $\begin{array}{c}64 \\
(16.0)\end{array}$ & $\begin{array}{c}58 \\
(14.5)\end{array}$ & $\begin{array}{c}40 \\
(10.0)\end{array}$ & $\begin{array}{c}42 \\
(10.5)\end{array}$ & $\begin{array}{l}35 \\
(8.7)\end{array}$ & $50 \%$ 以上 \\
\hline
\end{tabular}

資料 : 宇根の主要かつ重要な著作 401 点をもとに筆者作成. 本文 4. (2) も参照のこと.

1） 1 点の著作から複数の鍵概念を抽出している場合がある。 
を取り巻く環境や生態系に幅広く目が向けられるよ らになるのである。このことは「いきもの」「自然」 「環境」といら鍵概念の登場に示されて打り, 減農薬 運動の意義をより社会的な見地から捉えていこうと する変化の生じていることが理解できる.

やっと百姓の運動と自然保護運動が出会ってき ました. 百姓の側, 有機農業運動, 減農薬運動の 側も, 田んぼの生きものを豊かにしていく農法を 作り上げる過程で, 自然保護の人たちと出会うべ くして出会いつつあるのが現状です（宇根, 1993 : p. 51).

「ただの虫」といら用語が頻出するようになるのは 96 年である. 彼は第 1 期に扔いてすでに害虫でも益 虫でもない虫の存在を認識して抢り, これをさらに 概念として鍛えあげたのが「ただの虫」であった（宇 根, 1996). この概念によって, 彼は一面的な価值 基準の夕に立脚した「近代化技術」に対する批判の 橋頭堡を手に入れ，「『自然』だと思いこんでいるも のの本質」（宇根, 1998a：p. 22）へと切り込んでい くことになる.

同時にその作業は, 農業中心のまなざしからの脱 却にも繋がっていった。「稲作は赤トンボを田んぼで 育てる、ことでもあります」（宇根，1994：p. 24） との記述にも示されているように, 農業にとっての 自然の価値, 抢よび自然にとっての農業の価値とい ら, 双方向性をもった視点が確立し, これによって 脱生産主義的な思考へと舵を切る土壌が形成されて いくのである.

さらに, 減農薬稲作の社会的普及という観点から, 「環境支払い」や「デカップリング」に着目し始める のも第 2 期であり, 後に全国に先駆けて福岡県で実 施された「環境支払い」(2005〜) へと道を拓くこ ととなった（宇根，2005a：pp. 161-167）.

\section{（3）第 3 期：認識論指向期（2000～2010）}

50 才を目前にした宇根は, 農業の生みだす非経済 的な価值を共有できる社会ら゙くりに身を捧げる事を 決意し, 県職員を早期退職する。この転身による変 化は，「虫見板」および「ただの虫」への言及が急減 （それぞれ 7.9\%，10.0\%に低下）していることに表 れて扣り, 農業改良普及員として稲作農家に技術論
を語る初期のスタイルを脱し，世間一般の人々を対 象とする社会思想家へと立場を移行させていること が読み取れる。

転身後の彼は, 自ら結成した「農と自然の研究所」 の代表者として, 以前にも増して精力的に活動に取 り組んでいくそそこでの目的は，主として「カネに ならない“めぐみ”」の解明扣よび「田んぼの生きも のの全国調査」とされた（農と自然の研究所, 2020).

これらの活動を大別すると, ひとつには生物デー タの蓄積によって得られる説明力を背景にして, 現 実世界での社会的影響力を高めようとする路線が浮 かび上がる．もらひとつの路線は，生産効率に代表 される手段合理的な価値基軸に対する異議申乙立て と，日常生活に内在する「豊かさ」を探り出し評価 の沮上に上げること（=まなざしの涵養）であった。

前者の具体例として, 2000 年度から開始された農 業者等への直接支払い制度に,「生きもの」等の観点 の導入を目論む論考が挙げられる(「多面的機能」論 や「生物多様性」論)。制度化といらプラグマティッ クな評価体系の構築も, ひとつの有効な手段として 位置づけられたのである。ただし彼の思想は, 政治 的威光によって自説の強化を狙打うとする短絡的な 思考とは，明らかに一線を画するのであった．

現在「公益」だと言われ始めたものは，かつて は「私益」として，かえりみられなかったものば かりである．...ホタルが交尾しやすいよらにと残 した小川の横の茂み（私益）は, 生産効率を上げ るための圃場整備の邪魔になるといって, 伐ら机 てしまった．...いつから，ぞらいう理由で「私益」 は,「公益」に格上げされたのだろらか。釈然とし ないままである（宇根，2000：p. 10）

行政用語の色彩が濃い「多面的機能」は，そのま までは生産に従事する「百姓」の実感からかけ離れ ているとした上で，宇根は「百姓」の皮膚感覚に基 づいたボトムアップ型の視点の確立を唱えていた。

「風景」や「まなざし」にも触れて和こう。これら は「自然」や「生きもの」といった概念によって表 象される非経済的な価値を踏ま光，それらを日々の 暮らしの中でどのよらに認識し, 生活の中で体現し ていくかについて思索を巡らせる中で登場した用語 
である。

たと光ば「風景」は，守られるべき外在的価值と してのみならず，日々の生活の中で感じ取り，働き かけることのできる対象としても描かれていた。 つ まり「百姓」との相互作用を経ることで動的に生成 される価值，と考兄られているのである．その前提 には，「風景」を見つめ，そこに積極的な意義を与兄 よらとする「まなざし」の存在があった.

百姓にとっては風景は価值ではなく, 百姓仕事 の表出と認識されている。 だからこそ, 風景が荒 れてきたのは百姓仕事が手抜きになっているから だ，と不愉快になる。....百姓仕事の評価を「風景」 として，情感を込めて表現する習慣を打ち立てら れないだろらか（宇根, 2008a：p.1).

この時期の宇根は, 農的価值の認識・体現・共有 にまつわる総合的な体系化をめざして, 各種概念を 導入しつつ思考を巡らせていたのであった.

\section{（4）第 4 期：総括期（2011〜)}

「虫見板」のように途中から登場頻度の急減する用 語がある一方で，一貫して高い登場率を保っている 用語に「百姓」が挙げられる. この事実は, 宇根思 想の軸足のひとつが「百姓」に置かれてきたことを 如実に物語っている.

その際，第 1 期では技術と主体的に関係を取り結 ぶアクターとしての役割が期待されて和り, 減農薬 稲作は, 生産者の行政指導に対する盲従姿勢を改め させるために打ち出されたものに他ならなかった. それが第 $3 \sim 4$ 期になると,「百姓」は自然の恵みを 受容すると同時に創り出す立場として描かれるよう になる。すなわち「自然」と「百姓」の相補関係と いう捉え方の登場である.

百姓仕事は赤トンボを育てることを目的にして いるわけではないけれども, 百姓仕事は自然のめ ぐみを引き出すものだから，稲だけを引き出すわ けにはいかないことは誰でも知っています。「稲植 え」とは言わないで「田植え」と言うのがその名 残です (宇根, 2011a : pp. 3-4).

そこで描かれる「百姓」とは，積極的に「自然」
との互恵関係に身を委礼ることで豊かさを受け取り， 味わい，再生産に寄与寸る存在であった。 そしてこ の循環を認識し，能動的に関与していこうとする人 物のことであった：むろんそれは，宇根自身の希求 する理念的世界の体現者としての姿に他ならなかっ た．宇根は常に「百姓」に仮託する形で，自らの思 想を表現し続けてきた.

そしてこの時期の最大の特徵は，なんといっても 3 冊の単行本（2014-15 年）の主題となった「農本 主義」への傾倒である. 理念的存在としての「百姓」 像をさらに強化しょらとする試みの中で着目された 「農本主義」については，次節でさらに論じたい。

\section{6. 宇根思想の特質}

これまで述べてきたように，宇根は減農薬稲作の 確立・普及といら枠組及から出発しつつ,さま李ま な概念を取り込んでいくことで，論じる領域を広げ ていった，彼の特質を浮き彫りにするために，ここ では「有機農業」5 扣よび「農本主義」について考 えてみたい。

\section{（1）「有機農業」との距離感}

宇根はか㸚てより「有機農業」と深い関係を有し て扣り, 結成に関与した日本有機農業学会 (1999 年 〜）について次のように述べている.

有機農業学会は有機農業を研究対象にしている が, その目的は有機農業の振興にあるのではない. …近代化農業によって失われた「農」の本質を再 発見することにある．...私は「生産」の定義を力 ネにならないものまで広げ...その理論化を提言し ている (宇根, 2003a：p. 2).

ここからは有機農業の振興策の追求ではなく, 形 而上学的な観点から「農」や「生産」の「本質」に 迫っていこらとする意気込久が伝わってくる．とは いえ，学会設立に際して共通見解の到達に 2 年の時 間がかかっていること ${ }^{6}$, 特よび当初掲げられた「活 動方針 (案)」の過半にプラグマティックな事項が見 受けられることから（足立, 2001 : p. 220), 参加者 にとって振興策も関心事項のひとつであったことは 否めない.

したがって思惑の違いが存在していたからこそ， 
宇根は「有機農業」の信奉者ではなく，意見者とし ての立場を崩さなかったものと思われる。「有機農 業」に対する期待がどのような内容であったかにつ いては，以下の文章が端的に表現している.

有機農業は近代化農業への深い懐疑から生孔落 ちた。ところが,「農薬や化学肥料を使わない」農 業...といら定義を採用すると...生産性を向上させ ることに, 何ら疑問も抱かない有機農業もあり得 る...有機農業よ頑張るな. 経済性という価値観や, 安全といら当然すぎる価値とは違う...価值を求め て歩こう（宇根，2003b：p.2）.

宇根は, 彼自身の抱く理念と「有機農業」の間に ズレのあることを早くから自覚していた，そして後 者について，世間からの要請に素直に応じるだけで は不十分であることを嗅ぎ取っていた，次の文章は 「有機農業」の弱点を乗り越えていこうとする彼自身 の決意表明としても読むことができる.

有機農業は広がらないとぼやく百姓がいる．... それはその百姓の「運動論」が狭量だからだろら。 …地域に身を沈めて, 地域を表現する新しい言葉 を有機農業は生みださなければならない（宇根, 1998b : p. 51).

「新しい言葉」の具体的内容は, 第 2 期以降に登場 する「自給」「風景」といった鍵概念を見れば明らか である.さらに宇根は「地域を表現する」だけでな く，そのための方法論にまで視野を広げていく、そ して登場したのが「まなざし」であり，「有機農業」 はこれを回復するための有益な方策であるとされた。 つまり彼にとって「有機農業」とは, 理念世界々の ものではなく、「近代化農業が失った世界認識（自然 へのまなざし）を取り戻す」（宇根，2011b：p. 52) ための手段だったのである.

ここで興味深い一文を掲げて扢こう，自然農法の 福岡正信が宇根の琴線に触れたとする内容である.

科学への深い懐疑は, 有機農業には見られない。 そして，(自然農法には一引用者）自然への限りな い畏敬と没入がある。....近代」への懐疑と言っ
てもいい，昨今の有機農業にも，も5少し「科学」 への根源的な疑いがあってもいいのではないか(宇 根, 2005b: p. 2).

宇根は若い頃，実家の養鶏業が「近代化」してい くことに失望して家業継承を断念した経緯をもって 打り（佐藤弘，2008：pp. 22-24), 「近代」や「科 学」に対する批判的な「まなざし」は，実のところ， 彼の青年期からの最も基礎的な視点であった.

それだけに宇根は，農や食だけにとどまらず「近 代」や「科学」にまで視野を広げ，それを批判対象 として認識できるか否かといら点に深くこだわって いた．この点に関して，「有機農業」との間に譲るこ とのできない立場の違いが認識されていたからこそ， 彼は減農薬思想を「有機農業」と一体化させようと はしなかったのである。

むろん有機農業を標榜する人々の中にも批判精神 を発揮する人物は存在して和り，とりわ渾動初期 の 1970-80 年代には多くの論者が存在していたこと は留意せ补ばならない，たとえば自給農場運動であ る「たまごの会」で活躍した高松修は「科学」に対 する批判を繰り返し表明して打り（高松，1980）, 医師として有機農業運動に携わった梁瀬義亮も, 人々の健康という観点から「近代医学」や「近代農 学」を批判してきた (梁瀬, 1975).

だがこのような人物は参加者の拡大と共に次第に 少数派となり，「提携」運動や有機 JAS 規格の制定 といった社会的普及に主眼を和いた取り組みへと, 運動の重心が移っていったことは否めない，宇根の 求める方向性は，時代が下がるにつれて相対的に優 先順位を下げていったのである.

そして宇根は，減農薬思想を昇華させた先に広が り, 自らの思想を仮託できる概念を探し求めた結果, ある概念へと辿り着く、それが「農本主義」である.

\section{（2）「農本主義」への着目}

「農本主義」が登場するのは第 3 期である。これは 同思想に対する従来の学術的理解 7 の範囲を飛び越 えて，現代版の「農本主義」を新たに樹立しょうと する動きとして立ち現れた 8 .

「百姓仕事」とか「自然」とか「共同体」とか 「地域」とか「感性」とか,「公益的機能」などと 
様々に呼び名してはいるが，それらをひとくくり にする概念がまだ熟していない，ただ「新農本主 義」としか呼びようのないモノは, こうして確実 に生まれ，育ってきている（宇根，2002：p.2）.

やがて戦後の人物を「農本主義」と関連づけた論 考が出現する. 登場するのは熊本の松田喜一, 京都 の松井浄蓮, 佐賀の山下惣一などであり, 彼らの活 動は「労働」や「仕事」といら観点から評価されて いく，その意味で「農本主義」は，宇根の肯定でき る働き方を多分に包含した概念となっていた。

若い頃の私は（松田喜一について一引用者）「精 神論じゃないか」と近づけなかったが，百姓し始 めてから，理解できるようになった。....決して「労 働」といら言葉が出てこないのだ. たしかに,「労 働」といら言葉で語るようになった途端に, 何か が見えなくなるのである（宇根，2006：p. 107）。

やがて明治〜昭和初期の思想実態にも目が向けら れていく，焦点の当てられた人物は，「兄弟村農場、 の創設者で「五・一五事件」にも関わった樀孝三郎 である、だがこれらの人物は，結局のところ宇根を 満足させるには至らなかった。

私の関心は, 橘の著作を読みながら, 次第に移っ ていった．...社会主義革命と対極にあった農本主 義革命が輝いて見えるかもしれないといら期待は， 見事に裏切ら扎た（宇根，2010：p. 74）.

だが宇根は，先駆者への追随を諦めながらも，「農 本主義」論そのものを断念しょうとはしなかった. この概念は, 長年育んできた減農薬思想に拠り所を 与光, より高次の内容へと引き揚げてく机る可能性 を秘めていると考光たのである. 宇根は第 3 期以降, それまで提唱してきた様々な鍵概念の統合を試み ていた，その代表例として，宇根の独自性がよく示 されている「自給」論を見てみよう。

食べものの自給は, じつは農の自給なのであり， 村の自給であり，自然の自給であり，家族の自給 であり，遊びや喜び...つまり人生の自給であった。
…との中から食べものだけを「自給」の代表に抽 出した時から，それ以外が見光なくなった（宇根， 2008b : p. 61).

やがて彼は「自給こそ農本主義の源」（宇根， 2008c : p. 72) であると考光，「自給」を介在させる 形で「農本主義」を構築することを試み始める。

買った方が安いのに，田畑を耕して自給するの はなぜだろう。国家の経済成長よりも，在所の自 然と土と仕事が愛しいからである.ここにカネ（経 済）に対抗できる有力な思想がある。...私は静か でた拈やかな原理主義である新・農本主義を構想 したい（宇根，2009：p. 43）

このように宇根は，経済合理性という名の下で否 定され消滅しかかっている存在をすくい取るために, 「農本主義」によってそれらを表象しょらとした，彼 の「農本主義」論は，2014-15 年に出版された 3 部 作によって集大成を迎える。これらの著書では，減 農薬思想を唱えて以来，彼の議論の组上に上げられ てきた領域が，棌济網羅的に取り上げられていた。

簡単に 3 冊の違いを述べて抢こう。まず『農本主 義への誘い』（宇根，2014a）では，減農薬思想に端 を発した各種概念が「農本主義」といら名の下に統 合されていく道筋を描いており，いわば理論編であ る. 次に『愛国心と愛鄉心 新しい農本主義の可能 性』（宇根，2015）では，効率性という捉え方を生 み出す元凶として，自給率概念に内在するナショナ リズムが断罪され，生きものとの交感に根ざしたカ ネにならない価值を守るために，パトリオティズム という「まなざし」の重要性が説かれる。 3 冊目の 『農本主義が未来を耕す 自然に生きる人間の原理』 （宇根，2014b）では，これらの思想を日々の生活の 中で体現する理念上の人物像，すなわち「百姓」の あるべき姿が描かれる。な打 2016 年には，これら を新書版に読みやすくまとめた『農本主義のす寸め』 が出版され，「伝統」の創出に向けてさらなる決意が 述べられる（宇根，2016）。

ここからわかることは，宇根は「農本主義」を厳 密な定義をもった用語としてではなく，複数の鍵概 念に統合化をもたらす〈メ夕概念〉として扱ってい 
る点である ${ }^{9}$. 繰り返しになるが，彼の思索は農法 論から「自給」「百姓」にまで及ぶ広範なものであ る。 そ水沛涀代の農的思想から, 宇根の意を汲 むことのできる包括的概念を引き出すことは困難で あった。そこで彼は, 貨幣換算の困難な価值を守ろ らとする主張と親和的な存在を探し求めた結果, 古 典的な「農本主義」概念へとたどり着き，これに現 代的な意義を与えつつ再整備を試みたのであった。

\section{7. 現代版「農本主義」の意義}

最後に宇根が「農本主義」を選んだもらひとつの 理由について考光てみたい。

まず減農薬思想と「有機農業」の相違点を浮き彫 りにするために, 宇根の各種実践拈よび鍵概念を前 掲のモデル図（図 1）に沿って配置させたものが図 2 である。な扔議論の簡略化のため, 取り上げる実 践や鍵概念は重要なもののみに限定した ${ }^{10}$.

その結果，宇根思想では 4 つの辺上に実践抒よび 鍵概念の濃密な展開がみられ，とりわけ〈自然〉に ついてはそこを起点とする 3 辺すべてに該当事項が 存在していることから, 特に重要度の高い要素とさ れてきたことがわかる。逆に〈制度〉は 1 つの辺の みに事項が存在して括り，関心はさ核ど高くない， これらのことから〈自然〉〈間〉〈技術〉の 3 要素 によって囲ま机る三角形の面（図の灰色部分）が重 視領域であると判断できる.

ではこの領域をどのように解釈寸机ばよいであろ らか. この疑問を解くためには宇根思想を相対化す る作業が不可欠である。 そこで 1990 年代以降の有

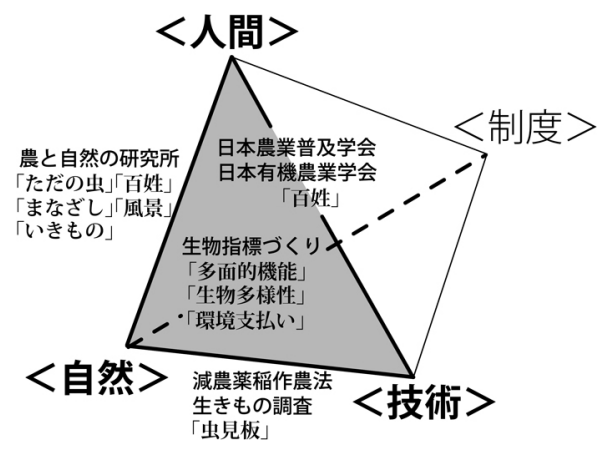

図 2. 宇根思想の展開方向

1）辺上のゴシック体は実践, 明朝体は鍵概念.

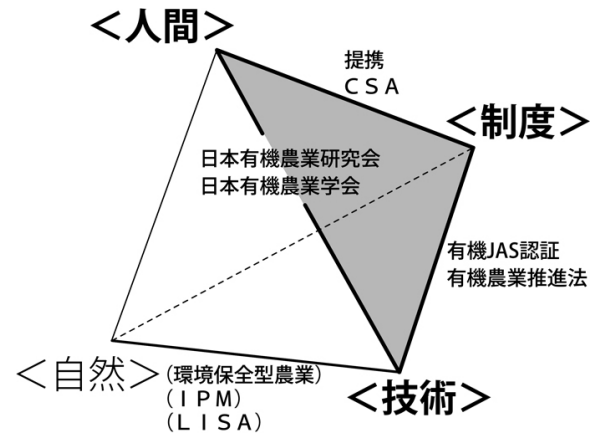

図 3. 有機農業の近年の展開方向 1）辺上に実践のみを示した。

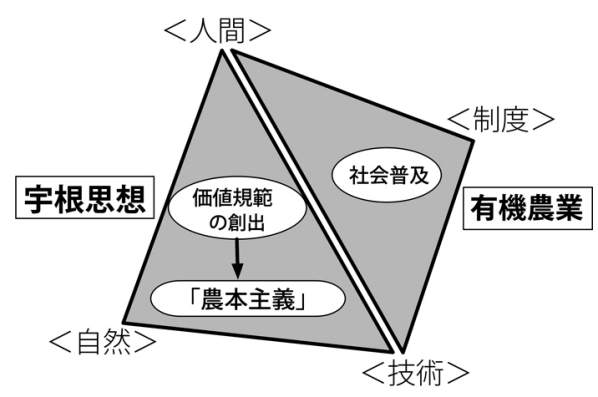

図 4. 宇根思想と有機農業の展開方向の違い

機農業についても軽く触れてみたい。その際，昨今 の有機農業では特定の人物を思想の代表者として抽 出することが困難なため，便宜的著名な実践展開 に限定して配置することとした（図 3)。その結果， こちらでは〈制度〉〈人間〉〈技術〉の 3 要素が浮か び上がることとなった

さらにそれぞれの重視領域を取り出して並べたも のが図 4 である。両者とも〈人間〉拈よび〈技術〉 に重きを扔く点で共通性を見せつつ，異なる点とし て宇根は〈自然〉を，有機農業は〈制度〉を選択し て打り，明確な路線の違いを見て取ることができる。 この違いは，さしずめ有機農業では社会普及に向け た実践として，宇根思想では新たな価値規範の創出 として理解できるように思わ机る.

といらのも宇根は「有機農業」を批判する際に, 価值論に対する関心の低さを根拠としてきたからで ある、その一方で彼は，日常でのあらゆる活動に拉 ける「自然」との関係性を価值規範の源泉と見なし， 
その内面化の実現を主張の柱に据えてきた ${ }^{11}$ 。それ ゆ光に「有機農業」が普及にむけて社会基盤の確立 に邁進してきたことと，宇根が「自然」に由来する 価値観の（個人での）内面化を唱光てきたこととは, 働きかけのベクトルが大きく異なっているのである.

さらに言光ば，「百姓」は宇根の思い描く理念像の 体現者に他ならず，彼は青年期からこの「百姓」の あるべき姿を表現しょらと試み続けてきた。 そこで 必要とされたのは, 各種の農的要素を包括的に含み, 社会変革に向けた信念を内包する鍵概念であった. 「農本主義」は，まさにこの課題に対する彼なりの回 答ではなかったかと思えるのである。

最後に付言して打くと，大正～昭和初期の「農本 主義」が，社会変革に向けた価値認識論としての意 味を強く持つことは重要である。一見すると宇根の 思想は, 旧来の「農本主義」の理解を大きく越光た 内容になっているものの，実は自己と「自然」をめ ぐる関係性を価值の源泉に据光ようとする思考法は, 岩崎正弥が明らかにした大正期の「〈自然〉委任型」 の事例を強く彷彿させるものであり（岩崎，1997： pp. 354-355)，この主題が時代を超えて通底する可 能性を垣間見せている。

その際，「自然」とより真摰に向き合った「農本主 義」者は，宇根が好んで取り上げた昭和恐慌期の橘 孝三郎よりも，むしろ大正期に活躍した「〈自然〉委 任型」（岩崎， $1997 ：$ p. 13）の石川三四郎たちであ ることを最後に付言しておきたい。

\section{注}

1 たとえば自給を掲げた運動がやがて有機農業へと辿り着いた 「農産物自給」運動が挙げられる（佐藤喜，1991）。

2 畑俊八と久松達央には，有機農業を絶対視することの弊害と 共に，それを乗り越えていこうとする視点の備わっているこ とがわかる（烟他，2017）。

3 安藤孫衛「食品公害から命を守る会」(福岡), 梁瀬義亮「慈 光会」(奈良), 大平博四（世田谷）などが挙げられる.

${ }^{4} \mathrm{x}-\mathrm{y}$ 軸型の平面モデルが 2 組の対立軸を用いる分析法である のに対し, 四面体型モデルでは 4 点からなる独立した要素 を，対立関係を用いることなく分析できる利点をもつ。

5 宇根の鍵概念として表記する際はカッコを付し, 一般的な意 味の有機農業と区別しておく.

6「『こだわり』が有機農業研究に打ける『価値観の相違』と なって表面化し，意思疎通の障害になることもあった」（足 立, $2001:$ p. 217).
7 舩戸修一（2009）による整理を参照のこと.

8 宇根の「農本主義」を批判的に分析した小林一穂は,「農本 主義をイデオロギーとして位置づけ」(p.3) ることで視点を 限定して分析を開始しながら，途中で「農本主義は...現実か ら遊離したイデオロギーとして成立」（p. 233）と述べて，概 念の全体規定へと転化させようとする（小林，2019）。これ は明らかにトートロジーであり, 農本主義研究に時折みられ る古典的な䛊謬に陥っている点を指摘できる.

9 同じく「新しい農本主義」に可能性を見いだす中島紀一は, 宇根とは逆に有機農業にくメ夕概念〉としての機能を持たせ て打り（中島，2013：pp.111-113），両者の間に類似した論 理構造を見て取ることができる.

10 表 2 に掲げた鍵概念のらち,「自然」「環境」「技術」は 4 要 素と重複するため，また「自給」はこの図では説明困難であ るため省略した。 また「百姓」は減農薬稲作に取り組む以前 からの重要課題であり, この概念の方向性を 1 つに絞り込む ことは難しいため，「百姓」のみ 2 方向に配置した.

11 自然と人間との関係を重視する姿勢は，かつて「やぼ耕作 団」を主催した明峯哲夫（2016）にも通じる。

\section{謝辞}

文献の提供を賜った宇根豊氏，ならびに丁重なる 審査とコメントを頂戴した査読者・編集委員会の皆 様に感謝申し上げます。

\section{引用文献}

明峯哲夫（2016）『生命を紡ぐ農の技術』コモンズ.

足立恭一郎（2001）「〈資料〉日本有機農業学会の設立までの経 過」日本有機農業学会 (編)『有機農業一 21 世紀の課題 可能性』年報 $1: 217-232$.

石田紀郎（2018）『現場とつながる学者人生一市民環境運動と 共に半世紀』藤原書店.

岩崎正弥（1997）『農本思想の社会史一生活と国体の交錯』京 都大学学術出版会.

宇根 豊（1977）「『手入れ』としての技術を問う」『日本作物 学会九州支部会報』 $43: 65$.

宇根 豊 (1984)『減農薬稲作のす寸好擬百姓舎（自費出版）. 宇根 豊（1993）「農を变光る減農薬運動」『地球環境・アジア NGO フォーラム報告書（2）一持続可能な農業分化会一』 $25: 42-51$

宇根 豊（1994）「環境は百姓の掌中にある」『公庫月報』 $42(8): 24-27$.

宇根 豊（1996）「農業が『自然環境』をつくる」『農業および 園芸』71(8)：17-23.

宇根 豊（1998a）「百姓仕事から見た自然環境」『技術と人間』 $27(5): 16-25$.

宇根 豊（1998b）「脱近代化運動としての有機農業」日本村落 
研究学会（編）『有機農業運動の展開と地域形成』年報 $33: 43-53$.

宇根 豊（2000）「百姓にとって，自然環境とは何なのか下

『多面的機能論』の限界之可能性」『農林経済』9298:8-13. 宇根 豊（2002）「新農本主義の誕生間近」『協同組合通信』

$14634: 2$.

宇根 豊 (2003a)「新しい学の誕生」『協同組合通信』14816:2.

宇根 豊 (2003b)「有機農業よ頑張るな」『協同組合通信』 $14937: 2$.

宇根 豊 (2005a)「農業政策に新しい政策スタイルを取り入れ る一環境支払いの思想を掘り下げながら一」日本有機農業 学会 (編)『有機農業法のビジョンと可能性』年報 $5: 153$ 168.

宇根 豊（2005b）「自然農法と有機農法の違い」『協同組合通 信』 $15279: 2$.

宇根 豊（2006）「労働をもら一度燃やせるか」『技術と普及』 43(3) : 106-107.

宇根 豊 (2008a)「風景の発見，その後」『農林経済』9961: 1 . 宇根 豊（2008b）「選択 vs 自給」『技術と普及』45(5)：60-61.

宇根豊（2008c）「自給こそ農本主義の源」『技術と普及』 45(10) : 72-73.

宇根 豊（2009）「あたりまえの農に向かって 新・農本主義 の時代へ」自治研中央推進委員会（編）『月刊自治研』 $601: 36-43$.

宇根 豊（2010）「橘孝三郎の内と外」山崎農業研究所（編） 『耕』120・121:74-76

宇根 豊 (2011a)「生きものから見た技術と仕事のちがい」『農 業普及研究』16(2) : 1-7.

宇根 豊（2011b）「生きものへのまなざし一百姓仕事の新しい 評価方法としての『環境支払い』を求めて」横川洋・高橋 佳孝（編著）『生態調和的農業形成と環境直接支払い 農 業環境政策論からの接近』青山社 : 49-117.

宇根 豊 (2014a)『農本主義へのいざない』創森社.

宇根 豊 (2014b)『農本主義が未来を耕す 自然に生きる人間 の原理』現代書館.

宇根 豊（2015）『愛国心と愛郷心 新しい農本主義の可能性』 農山漁村文化協会.

宇根 豊 (2016)『農本主義のす寸め』ちくま書房. 大石和男 (2017) 「藤本敏夫の『自給』構想にみる〈理念距離〉
の意味」『ソシオロジ』62(2) : 21-38.

小林一穂 (2019) 『農本主義と農業者意識一その理念と現実一』 御茶の水書房.

佐藤喜作（1991）『農業が築く自給自立運動一秋田県・仁賀保 町農協の実践一』家の光協会.

佐藤 弘（2008）『宇根豊聞き書き 農は天地有情』西日本新 聞社.

高松 修 (1980)『石油タンパクに未来はあるか』績文堂出版. 谷川彩月（2017）「慣行農家による減農薬栽培の導入プロセス 一宮城県登米市での『環境保全米』生産を事例として一」 『環境社会学研究』23:114-129.

谷口吉光（1989）「『生活者』の形成 有機農業運動に打ける関 係変革の諸相」『社会学年報』X VIII : 79-94.

中島紀一 (2013) 『有機農業の技術とは何か 土に学び，実践 者とともに』農山漁村文化協会.

中村貴子（2009）「多様な生き物と共存する農の豊かさ一自然 キャピタル—」『農林業問題研究』44(4) : 498-507. https:// doi.org/10.7310/arfe1965.44.498.

農と自然の研究所（2020）https://hb7.seikyou.ne.jp/home/N-une/ 2-a-2-kennkyuusyonokatudoukeikaku.htm (2020 年 5 月 20 日 参照).

畑 俊八・久松達央・添田 潤 (2017) 『有機農業』は終わっ たのか？前編」全国愛農会（編）『月刊愛農』4月号： $2-9$.

原山浩介（2008）「喪失の歴史としての有機農業一『逡巡の可 能性』を考学る」池上甲一・岩崎正弥・原山浩介・藤原辰 史『食の共同体一動員から連帯へ』ナカニシヤ出版 : 119176.

藤井平司 (1983) 『㿡えれ! 天然農法』新泉社.

福岡正信 (1975) 『自然農法・わら一本の革命』柏樹社.

舩戸修一 (2009) 『農本主義』研究の整理と検討」『村落社会 研究』16(1) : 13-24.

桝潟俊子（2017）「有機農業運動の展開にみる〈持続可能な本 来農業〉の探求」『環境社会学研究』 $22: 5-24$. https:// doi.org/10.24779/jpkankyo.22.0_5.

梁瀬義亮（1975）『有機農業革命一污れなき土に播け一』ダイ ヤモンド社.

有機農業研究会（編）（1972）「有機農業研究会結成趣意書」『た べものと健康』No.1: 表紙裏. 